\title{
Analysis of the beef supply in Veracruz, Jalisco and Chiapas states, Mexico, 2000-2019
}

\author{
Rebollar-Rebollar, Eulogío; Rebollar-Rebollar, Samuel ${ }^{1}$; Guzmán-Soria, Eugenio ${ }^{2}$; \\ Hernández-Martínez, Juvencio ${ }^{3}$; González-Razo, Felipe de Jesús ${ }^{4}$
}

\begin{abstract}
${ }^{1}$ Universidad Autónoma del Estado de México, Barrio de Santiago sn Temascaltepec, Estado de México. ${ }^{2}$ Instituto Tecnológico de Celaya, Av. Tecnológico y A. García Cubas S/N. ${ }^{3}$ Universidad Autónoma del Estado de México, El Tecojote, Texcoco, Estado de México; ${ }^{4}$ Universidad Autónoma del Estado de México, Rincón de Aguirre, Tejupilco, México.
\end{abstract}

Corresponding author: srebollarr@uaemex.mx

\begin{abstract}
Objective: to determine the effect of the variables that impact the supply of beef in Veracruz, Jalisco and Chiapas states, Mexico, from 2000 to 2019

Methodological design/approach: a multiple linear regression model was used; where the supply was the dependent variable and the price of beef, corn price and annual rainfall were the explanatory variables.

Results: the dynamics of the beef production in Veracruz, Jalisco and Chiapas were directly and inelastically explained by its price with a value of $0.89,0.13$ and 0.49 ; inversely and inelastically by the price of corn $(-0.05,-0.005$ and -0.05$)$ and directly and inelastically by the state annual precipitation $(0.16,0.01$ and 0.21$)$.

Study limitations/implications: it is suggested to test the statistical and economic significance with the Cobb-Douglas supply models to contrast their elasticities.

Findings/conclusions: the variable that explained the dynamics of bovine production in these Mexican states was the price of the product, while the price of corn was the one with the least impact.
\end{abstract}

Keywords: cattle, elasticities, price, econometric model, production

\section{INTRODUCTION}

Protein of animal origin is basic in people's diets; the main sources are poultry, beef and pork. In 2019, Mexico produced 7.22 million tons ( $\mathrm{mt}$ ) in carcass of these species, $48.11 \%$ poultry meat, $28.06 \%$ cattle, $22.14 \%$ to swine and the rest $1.69 \%$ to sheep, goats and turkeys (SIAP, 2020). Beef meat is the muscle tissue, accompanied or not by connective tissue, bone and fat, as well as nerve fibers, lymphatic vessels, which come from slaughter animals (CIMA, 2018).

In Mexico, beef is one of the most significant consumed meat due to its high protein value and its social and economic importance (Puebla et al., 2018) and is considered the second most important productive activity, from the productive point of view (SIAP, 2020); however, the productive structure in this sector has undergone substantive modifications at the regional level. From 2000 to 2019, the national volume of beef registered an average annual growth rate (TCMA) of $2.06 \%$, going from $1.40 \mathrm{mt}$ in 2000 to $2.02 \mathrm{mt}$ in 2019 (SIAP, 2020).

\section{Agroproductividad: Vol. 14, Núm. 3, marzo. 2021. pp: 87-93.}


The dynamism of bovine production in Mexico showed disparities among the States that comprise it (Puebla et al., 2018). In 2019, the region (entities) of Veracruz, participated with $13.02 \%$ (208.13 thousand t); Jalisco contributed $11.82 \%$ ( 188.94 thousand $t$ ) and Chiapas contributed 5.23\% (83.60 thousand $t$ ); together, these three regions contributed $30.08 \%$ of the national production (SIAP, 2020).

Therefore, the beef production behavior among the aforementioned entities in Mexico was different. The objective here was to determine the effect of the variables that impacted on the beef supply in Veracruz, Jalisco and Chiapas states, México, during the year 2000 to 2019, in order to generate recommendations that allow the design of strategies to support beef production in a regional scope. The main hypothesis indicates that the supply of beef in the three states of Mexico responds positive and inelastically to the price of the product, is negative and inelastic to the price of its input, and positive and inelastic to rainfall.

\section{MATERIALS AND METHODS}

The supply of carcass beef was analysed in the states of Veracruz (Ver), Jalisco (Jal) and Chiapas (Chis), Mexico, from 2000 to 2019, as these are the most important entities to produce this meat, which represent little more than $30 \%$ of the national volume.

For this, a multiple linear regression econometric model (MLR) was specified for each region in which three fixed, independent or predetermined variables were included as determinants for the supply of this meat product, in addition to the delayed dependent variable as conclusive or exogenous of the current offer for the case of Jal and Chis states.

In the estimation of the model, cross-sectional secondary information was used from official sources in Mexico, such as SIAP (2020), Fideicomisos Instituidos en Relación a la Agricultura (FIRA) (FIRA, 2020) and the Sistema Nacional de Información e Integración de Mercados (SNIIM) (SNIIM, 2020) (SNIIM, 2020).

The monetary variables were deflated with the Índice Nacional de Precios al Productor (INPP) base 2019=100 (INEGI, 2020).

The estimation of the value of the model parameters associated with the supply function was performed via the Ordinary Least Squares (OLS) method (Gujarati and Porter, 2010) in the SAS statistical software (Statistical Analysis System) version 9.1.3 (SAS, 2003).

The statistical congruence of the supply models was determined with the adjusted $\mathrm{R}^{2}$-coefficient of determination. The global statistical significance of the models was assessed with the value of the calculated-F and the individual significance of each coefficient linked to each predetermined variable performed with the Student's t test or the "t ratio". Results of the statistical tests of the Durbin-Watson (DW) were added for the autocorrelation degree, White for multicollinearity and Breusch-Pagan
(BP) for heteroscedasticity, which showed the results output of each of the models.

The economic significance was carried out taking into account the signs and magnitude of the coefficients of the fixed variables of the estimated models, interpreted with respect to the micro economic theory; that is, the relation between the supplied quantity, and the beef carcass price, as well as the supply with rainfall, which must be direct; while with the price of corn, the relationship should be inverse.

In some regions, the corn price and precipitation variables lagged one or two years because the producers do not immediately react to a change in prices or fluctuations in the rainfall in the study areas, by decreasing or increase production. Nonetheless, also to factors such as the duration of the productive cycle of the animals, the degree of investment, the production volume and financial situation of the trade, so this procedure is different in the different producing areas of the country (Puebla et al., 2018), because in the market, in this case, the response of supply to changes in its determining factors is rarely instantaneous.

This is even more evident for the case of the supply of agricultural products, in which, due to the biological process, they need a period for their production. They often respond after a certain time, a period that called "lag" or "delay" (Gujarati and Porter, 2010). The cited model assumed that some of the exogenous variables are influenced by one or two lag periods, which was statistically justified based on its individual significance. 
The economic elasticities of each of the explanatory variables that determined the beef supply in each of the studied regions were also calculated, through the observed average of the period and evaluated according to the sign and magnitude of their coefficients (Nicholson and Snyder, 2015; Parkin and Loría 2015; Rebollar et al., 2019). The statistical specification of the econometric models to determine the behavior of the beef supply in the evaluated states was:

$$
\begin{aligned}
& B M O_{t}=\beta_{11}+\beta_{12} B R P_{t}+\beta_{13} P R M_{t}+\beta_{14} M P_{t-1}+f_{t} \text { (Veracruz) } \\
& B M O_{t}=\beta_{21}+\beta_{22} B R P_{t}+\beta_{23} P R M_{t}+\beta_{24} M P_{t-1}+\beta_{25} B M O_{t+1}+f_{t} \text { (Jalisco) }
\end{aligned}
$$

$$
B M O_{t}=\beta_{31}+\beta_{32} B R P t+\beta_{33} P R M_{t}-2+\beta_{34} M P_{t-2}+\beta_{35} B M O_{t+1}+f_{t} \text { (Chiapas) }
$$

Where $B M O_{t}$ : Supply of beef carcass during the study period, approximate to the state production of this product, figures in tons $(\mathrm{t})$; $B R P_{t}$ : real price of beef carcass, in pesos per ton $(\$ / t)$; $B R P_{t-2}$ : real price of beef carcass, with a two-year lag in pesos per ton $(\$ / t)$; $M P_{t}$ : mean rainfall in millimeters during the current period (millimeters); $M P_{t-1}$ : one-year lag rainfall in millimeters (thousand); $M P_{t-2}$ : two-year lag of rainfall in millimeters (thousand); $B M O_{t-1}$ : one year lag state beef supply, figures in tons.

Regarding the prices of beef and corn, the first was determined through the real price of the product in carcass. For the price of feed, the real price of corn (grain) was considered as the main component in the diet of cattle (Puebla et al., 2018).

To calculate the elasticity of supply value related to each of the explanatory variables, the coefficient of the partial derivative of the estimated model was multiplied by the average observed value of each of the independent variables with respect to the supplied quantities (Gujarati and Porter, 2010; Guzmán et al., 2012; Rebollar et al., 2019). Considering that the linear supply function has a variable elasticity in its estimation range; For this reason, it was determined for the average of the analyzed period (Sheperd, 2006; Puebla et al. 2018; Rebollar et al., 2019); and with the above, the effects established in the functional relationships were quantified.

\section{RESULTS AND DISCUSSION}

The results obtained from the supply models estimated in their linear form in each of the three states (entities) of Mexico, are presented in Table 1.

The MLR models estimated for the supply of beef in Ver, Jal and Chis, period 2000-2019, were:

$$
\begin{aligned}
& B M O_{t}=-24.764+1.179 B R P_{t}-0.940 P R M_{t}+8.80 M P_{t-1}(\text { Veracruz) } \\
& B M O_{t}=-9.613+0.372 B R P_{t}-0.191 P R M_{t}+3.296 M P_{t}+0.795 P B_{t-1} \text { (Jalisco) } \\
& B M O_{t}=-24.907+0.717 B R P_{t}-0.932 P R M_{t}-2+8.664 M P_{t}-2+0.270 P B_{t-1} \\
& \text { (Chiapas) }
\end{aligned}
$$

The goodness of fit, given by the adjusted coefficient of determination $\mathrm{R}^{2}$, was 0.86 (Ver), 0.98 (Jal) and 0.88 (Chis); which means that, of all the source of total variation of the estimated models, $86 \%, 98 \%$ and $88 \%$, was explained by the exogenous variables included in them. The difference to the $100 \%$ was due to other variables that were not included in this research.

With respect to the value of the calculated-F statistic (FC), for a total of $n=20$ observations, the models were statistically significant with values of 39.03, 179.40 and 30.75 , (Table 1). Therefore, statistically, there was no beta equal to zero when performing the hypothesis test at any level of reliability. As a whole, all the exogenous variables have the capacity to explain the behavior of the dependent or explained variable (beef supply in Ver, Jal and Chis, México).

In all the explanatory variables, the value of the calculated $t\left(t_{c}\right)$, associated with each estimator, was greater than the unit, a scenario that indicates that the value of the estimated parameter is greater than twice its standard error (Brigham and Pappas, 1992; Pérez et al., 2010); favorable situation from the point of view of the efficiency of the results that emerge from it.

Under this argument, all the coefficients of the independent variables were statistically significant and their signs and congruent with the microeconomic theory in terms of the law of supply (the direct relationship with the price of the product, inverse with the price of the input and direct with rainfall). 


\begin{tabular}{|c|c|c|c|c|c|c|c|c|}
\hline Region & Dependent variable & Intercept & \multicolumn{4}{|c|}{ Explanatory variables } & $\mathrm{R}^{2}$ adj & Prob $>F$ \\
\hline \multirow{8}{*}{$\begin{array}{l}N \\
\frac{N}{U} \\
\frac{U}{U} \\
\stackrel{D}{>}\end{array}$} & $O C B_{t}$ & & $\mathrm{PRB}_{\mathrm{t}}$ & $\mathrm{PRM}_{\mathrm{t}}$ & $P P_{t-1}$ & & 0.86 & 0.0001 \\
\hline & Coeficient & -24.764 & 1.179 & -0.940 & 8.809 & & & \\
\hline & SE & 10.444 & 0.368 & 0.269 & 3.764 & & & \\
\hline & t value & -2.370 & 3.210 & -3.500 & 2.340 & & & \\
\hline & DW & 1.775 & & & & & & \\
\hline & $\mathrm{BP}$ & 4.420 & & & & & & \\
\hline & White & 5.030 & & & & & & \\
\hline & F value & 39.030 & & & & & & \\
\hline \multirow{8}{*}{ 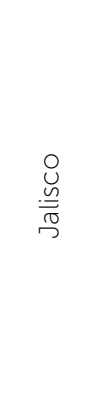 } & $\mathrm{OCB}_{t}$ & & $\mathrm{PRB}_{\mathrm{t}}$ & $\mathrm{PRM}_{\mathrm{t}}$ & $P P_{t}$ & $O C B_{t-1}$ & 0.98 & 0.0001 \\
\hline & Coeficient & -9.613 & 0.372 & -0.191 & 3.296 & 0.795 & & \\
\hline & SE & 3.382 & 0.104 & 0.097 & 1.208 & 0.101 & & \\
\hline & t value & -2.840 & 3.570 & -1.970 & 2.730 & 7.840 & & \\
\hline & DW & 2.008 & & & & & & \\
\hline & $\mathrm{BP}$ & 6.000 & & & & & & \\
\hline & White & 6.620 & & & & & & \\
\hline & F value & 179.400 & & & & & & \\
\hline \multirow{8}{*}{$\begin{array}{l}\tilde{N} \\
\frac{0}{0} \\
\frac{0}{\tilde{U}}\end{array}$} & $\mathrm{OCB}_{\mathrm{t}}$ & & $\mathrm{PRB}_{\mathrm{t}}$ & $\mathrm{PRM}_{t-2}$ & $P P_{t-2}$ & $P B_{t-1}$ & 0.88 & 0.0001 \\
\hline & Coeficient & -24.907 & 0.717 & -0.932 & 8.664 & 0.270 & & \\
\hline & SE & 6.905 & 0.294 & 0.249 & 2.405 & 0.178 & & \\
\hline & t value & -3.610 & 2.440 & -3.740 & 3.300 & 1.510 & & \\
\hline & DW & 2.388 & & & & & & \\
\hline & $\mathrm{BP}$ & 4.710 & & & & & & \\
\hline & White & 9.690 & & & & & & \\
\hline & F value & 30.750 & & & & & & \\
\hline
\end{tabular}

Source: own elaboration, based on SAS output. SE: standar error. BP: Breusch-Pagan. DW: Durbin-Watson.

The DW statistic indicated a low level of autocorrelation between the time series, due to the nature from which the information came; while the result of the BP and White calculated in the three models indicated the absence of heteroscedasticity between the explanatory variables (Gujarati and Porter, 2010), and based on the results of the three models in terms of the adjusted $R^{2}$, the Fc, the value of the standard error and the tc was indicative of no evidence of multicollinearity between the series (Gujarati and Porter, 2010), so the unbiasing and efficiency properties of the OLS estimators are present.

Under the microeconomic theory approach, the estimated models were significant, because the expected signs in each of the estimators were congruent. In other words, a positive sign was expected in the price of beef and precipitation and a negative sign for the price of corn (input price).

Thus, for the assessed period, in Veracruz, Jalisco and Chiapas, the supply of beef was explained both by the behavior of the price received by the producer, as well as by the behavior of the price of corn grain and the annual rainfall.

\section{Economic analysis: elasticities}

The supply of any good, is overall, a function of the price of the product, the inputs price, the climate, as well as the technology (Salvatore, 1977). In each of the three estimated MLR models, the elasticity value related to its explanatory variable (Table 2), required the usage of the series' average; for example, for Jalisco, the beef carcass price was \$64,869.61/t (Mexican pesos per ton); for corn grain $\$ 4,409.25 / \mathrm{t}$ and rainfall of 823.90 millimeters (thousand), when replacing these values in the estimated supply model, the result was 182,030.64 t of beef carcass. 
With the above information, for Jalisco (Jal) the price elasticity of the beef supply was:

$$
\varepsilon_{p}^{\circ}=(0.372)\left(\frac{64869.61}{182030.64}\right)=0.132
$$

Similarly, for the same variable in Ver and Chis, and the fixed of corn price, rainfall, and production delay variables.

For the 2000-2019 period, the beef supply in Ver, Jal and Chis, México, was explained by the behavior that the price received by the meat producers of this species, due to the price of feed (corn grain), rainfall and the delayed production variable in the case of Jal and Chis.

In the LRM model, for Ver, the intercept term $(-24,764)$ lacks of economic interpretation or is of secondary importance (Gujarati and Porter, 2010), as in Jal and Chis, because it is not possible to understand the supply of beef in such a quantity (in this case negative supply associated with the intercept with a negative sign), when all the explanatory variables occupy a value of zero; analogous to that reported by Rebollar et al. (2008) on a response function in sheep from the south Estado de Mexico, México; however, 1,179 (Table 1), which is the assigned coefficient to the price of beef in Ver, expresses that during the analysis period, for every thousand Mexican pesos, as a monetary unit (US\$50.00), in increase price for the meat producer (ceteris paribus=everything else constant), the quantity of supplied beef is expected to increase by 1,179 t. of corn (feed price) (ceteris paribus), the supply of beef is expected to distance itself by $191 \mathrm{t}$. Likewise, for each unit of increase in rainfall (ceteris paribus), the quantity of offered beef shows a $795 \mathrm{t}$ increase.

Regarding Chis, for every thousand pesos of increase in the price of the product, the quantity of beef offered will increase by $717 \mathrm{t}$; whereas, due to the increase of one thousand pesos in the corn price, the supply will decrease by $932 \mathrm{t}$ and, as rainfall increases by one unit, the quantity of supplied beef will be increase in $8.66 \mathrm{t}$ (Table 1). Elasticity, by itself, does not help (Nicholson and Snyder 2015; Parkin and Loría 2015), but when relating it to variables that explain a certain market, then it has attractive interpretations (Vázquez and Martínez, 2015).

In its theoretical form, the term elasticity states how sensitive a dependent variable is to unit percentage variations of the predetermined variable. Consequently, the price elasticity of supply; in this case, for beef in Ver, Jal and Chis, México, can be elastic (greater than unity), inelastic (whose value is between zero and one) or unitary (equal to one). When the elasticity is unitary, it means that the percentage increases in prices of the good generate percentage increases in the supplied quantities of this in the same proportion. If the magnitude is less than 1.0, the elasticity is said to be inelastic and its effect is that the quantities supplied react little to changes in the price of the product. The values of the elasticities of the price of supply of a greater than one magnitude reveal that the percentage changes in prices have a more than proportional impact on the good's supply; in this case it is stated that the elasticities are high, and the supply is elastic.
Consequently, for every thousand pesos in which the price of a ton of corn (food price) increases (ceteris paribus), it is expected that the state supply of beef will decrease by 940 t. Additionally, for each increase unit in rainfall (ceteris paribus), it is expected that the quantity of offered beef will be reflected in an increase of 8,809 t of that meat.

In the case of Jal, for every thousand pesos increase in the price for the beef producers, the supply in that entity is expected to increase by 372 $t$ and an inverse effect on the price

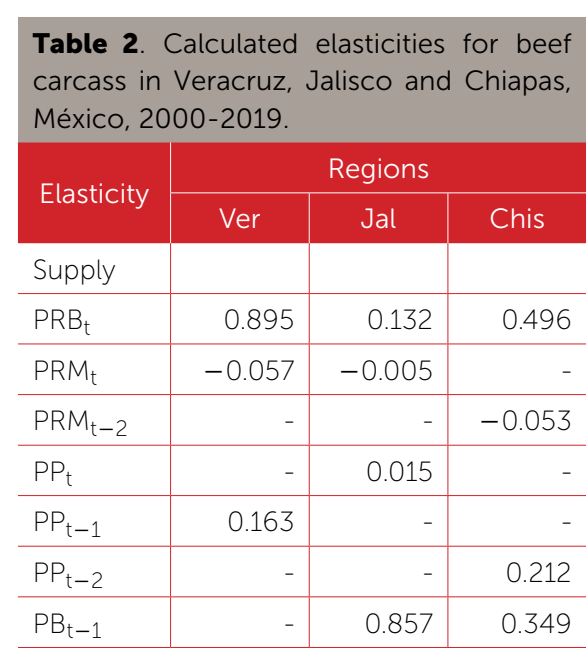

Source: calculations based on the results of the estimated model.
When analyzing the information in Table 2, the price to the beef producer in Ver, Jal and Chis, México, had an inelastic effect during the evaluated period, because increases of $1 \%$ in the price of this meat increase the quantity offered of the meat product by less than $1 \%(0.89,0.13$ and 0.49$)$; the quantity of beef offered responds less than proportionally to an unit increase in its price; However, the greatest effect of the changes in the price of the product was in Ver (0.89) and the least impact in Jal 
(0.13). Research related to this finding was not found sufficiently; however, such a result is consistent with those reported by other researchers such as Castro et al. (2019) (0.38); Puebla et al. (2018) (0.06); Vázquez and Martínez (2015) (0.67); Cruz and García (2014) (0.34); Ramírez et al. (2011) (0.03); Benítez et al. (2010) (0.12), confirmed positive and inelastic values of the beef supply related to its price. The response of beef with respect to the expected price of corn (as the main feed component) responded in an inverse and inelastic way. Although it is an important input for meat production of this livestock species, the dynamics in its price does not significantly affect its production in the aforementioned entities; however, the results are similar to those reported by Castro et al. (2019) (-1.47), Puebla et al. (2018) (-0.07), and Cruz and García (2014) (-0.33). However, the elasticity magnitude varies between the different studies because they evaluate different periods; however, the reverse character remains.

The response of beef in the three evaluated states to the effect of their mean annual precipitation was direct and inelastic (0.16, 0.01 and 0.21); therefore, their unit percentage increases would mean increases of less than one percentage unit in the beef supply. Such results concur with those by Puebla et al. (2018), where during 1994-2013 period, obtained an elasticity for the supply of beef in different regions of Mexico in relation to the precipitation of 0.06

The response to the supply of beef in Jal and Chis, regarding the supply delay in one period, was positive and inelastic; that is to say, knowing the behavior of the supply of the previous year has tangible effects of less than one percentage unit on the current supply of beef.

\section{CONCLUSIONS}

The elasticities of the supply of carcass meat in Ver, Jal and Chis, Mexico, in relation to each of the explanatory variables, showed that the factor that most influenced the growth of bovine production was the price of the product, with highest effect in Ver, followed by the annual state precipitation, accentuated in the state of Chiapas. The price of corn in the production of the evaluated species was not appreciable.

\section{REFERENCES}

Benítez-Ramírez, J.G., García-Mata, R., Mora-Flores, J.S. y GarcíaSalazar, JA. (2010). Determinación de los factores que afectan el mercado de carne bovina en México. Agrociencia 44(1): 109
119. https://agrociencia-colpos.mx/index.php/agrociencia/ article/view/781/781. (10/06/2020)

Brigham, F.E. y Pappas, L.J. (1992). Economía y Administración. México, D. F.: Mc Graw Hill.

Castro-Samano, M.A., García-Mata, R., Parra-Insunza, F., PortilloVázquez, M., Márquez-Sánchez, I., García-Sánchez, R.C. (2019). El mercado de la carne de bovino en México, considerados los factores externos. Agricultura, Sociedad y Desarrollo 16(1): 85-103. https://doi.org/10.22231/asyd.v1i1.982. (20/06/2020).

CIMA. Centro de Información de Mercados Agroalimentarios. 2018 Reporte del Mercado de la Carne de Bovino. Consultado 20 de marzo 2020. Recuperado de https://www.cima.aserca.gob. mx/work/models/cima/pdf/cadena/2018/Reporte_mercado_ bovino_200618.pdf. (18/05/2020).

Cruz-Jiménez, J., García-Sánchez, R.C. (2014) El mercado de la carne bovina en México, 1970-2011. Estudios Sociales 22(43): 89-109 https://www.ciad.mx/estudiosociales/index.php/es/article/ view/4. (07/05/2020).

Gujarati, N.D. y Porter, D.C. (2010). Econometría. México, D. F. McGraw-Hill Interamericana.

Guzmán-Soria, E., de la Garza-Carranza, M.T., García-Salazar J.A., Hernández-Martínez, J., Rebollar-Rebollar, S. (2012) Determinantes de la oferta de maíz grano en México Agronomía Mesoamericana 23(2): 269-279. http://www.mag go.cr/agronomia_mesoamericana/index.html. (30/05/2020).

INEGI. Instituto Nacional de Estadística, Geografía. Banco de información Económica. (2020). Recuperado de https://www inegi.org.mx/sistemas/bie/. (09/06/2020)

Nicholson, W., Snyder, C. (2015). Teoría Microeconómica Principios básicos y ampliaciones. México, D.F.: Cengage Learning

Parkin M. \& Loría E. (2015). Microeconomía, un Enfoque para América Latina. México, D. F.: Pearson Educación.

Pérez-Vera, F.C., García-Mata, R., Martínez-Damián, M.A., Mora-Flores, J.S., Vaquera-Huerta, H., González-Estrada, A. (2010). Efecto de las importaciones de carne de porcino en el mercado mexicano, 1961-2007. Revista Mexicana de Ciencias Pecuarias 1(2):115-126. https://cienciaspecuarias.inifap.gob.mx/index php/Pecuarias/article/view/1517. (17/06/2020).

Puebla-Albiter, S., Rebollar-Rebollar, S., Gómez-Tenorio, G., HernándezMartínez, J., Guzmán-Soria, E. (2018). Factores determinantes de la oferta regional de carne bovina en México, 1994-2013 Región y Sociedad 30(72): 1-17. https://regionysociedad colson.edu.mx:8086/index.php/rys/article/view/895/1209 $(18 / 05 / 2020)$

Ramírez-Tinoco, J., Martínez- Damián, M.A., García-Mata, R., Hernández-Garay, A., Mora-Flores, J.S. (2011). Aplicación de un sistema casi ideal (AIDS) a cortes de carnes de bovino, porcino, pollo, huevo y tortilla en el periodo de 1995-2008. Revista Mexicana de Ciencias Pecuarias 2(1): 39-52. https:// cienciaspecuarias.inifap.gob.mx/index.php/Pecuarias/article/ view/1455. (27/05/2020)

Rebollar-Rebollar, S., Hernández-Martínez, J., Rojo-Rubio, R., GonzálezRazo, FJ., Mejía-Hernández, P., Cardoso-Jiménez, D. (2008) Óptimos económicos en corderos Pelibuey engordados en corral. Universidad y Ciencia 24(1): 67-73. http://era.ujat.mx/ index.php/rera/article/view/281/232. (26/05/2020)

Salvatore, D. (1997). Teoría y problemas microeconómicos. México, D.F.: McGraw-Hill. 
Rebollar-Rebollar, E., Rebollar-Rebollar, S., Guzmán-Soria, E. (2019). Determinantes de la oferta de carne de pollo en México. Panorama Económico 27(2): 336-348. https://doi.org/10.32997/2463-0470vol.27-num.2-2019-2632. (05/06/2020).

SAS (Statistical Analysis System). (2003). SAS Versión 9.1.3. N.C., USA: SAS Institute Inc, Cary.

Shepherd, B. (2006). Estimating price elasticities of supply for cotton: a structural time-series approach. FAO Commodity and Trade Policy research, working paper no. 21. Francia. Recuperado de http://www. fao.org/3/a-ah470e.pdf. (17/06/2020).

SIAP. Servicio de Información Agroalimentaria y Pesquera. (2020). Anuario Estadístico de la Producción Ganadera. Recuperado de https:// nube.siap.gob.mx/cierre_pecuario/. (09/06/2020).

Vázquez-Alvarado, J.M.P., Martínez-Damián, M.A. (2015). Estimación empírica de elasticidades de oferta y demanda. Revista Mexicana de Ciencias Agrícolas 6(5): 955-965. https://cienciasagricolas.inifap. gob.mx/index.php/publicaciones. (12/08/2020).

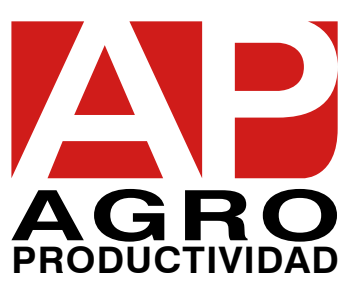

